\title{
Wpływ czynników środowiskowych na rozwój raka pęcherza moczowego
}

\author{
Anna Długosz, Justyna Gąsior, Anna Guzik
}

W każdym roku notuje się wzrastającą liczbę przypadków raka pęcherza moczowego (UBC). Analiza globalna z 2009 roku wykazała 2,7 mln zdiagnozowanych pacjentów. Ze względu na rosnące wskaźniki zachorowań oraz wysokie koszty leczenia bardzo ważne wydaje się być zidentyfikowanie czynników ryzyka rozwoju UBC oraz zastosowanie procedur prewencyjnych wśród osób narażonych. Do czynników środowiskowych mających najsilniejszy oraz udowodniony wpływ na rozwój UBC należą: palenie tytoniu, aminy aromatyczne, wielopierścieniowe węglowodory aromatyczne, nitrozoaminy, związki arsenu i kadmu oraz niektóre leki. Badania eksperymentalne wskazują na kancerogenne działanie niektórych pestycydów z grupy karbaminianów oraz pochodnych chloroorganiczych w obrębie nabłonka urotelialnego. Ważną rolę przypisuje się także procesom zapalnym, towarzyszącym zakażeniom Schistosoma haematobium, ekspozycji na promieniowanie jonizujące oraz terapię immunosupresyjną. Natomiast w odniesieniu do palenia biernego, produktów chlorowania wody, ekspozycji na chlorowcowęglowodory, azotyny oraz azotany konieczne są dalsze badania w celu jednoznacznego określenia ich roli w rozwoju UBC. W raku pęcherza związek między ekspozycją środowiskową a zapadalnością jest wyraźniejszy niż w innych nowotworach. Najważniejszym czynnikiem sprawczym wydają się być interakcje czynników środowiskowych z genetyczną wrażliwością. Wskazują na to m.in. badania genotypu GST, NAT oraz innych enzymów detoksykacyjnych. Predyspozycje genetyczne odgrywają zatem ważną rolę i strategia prewencji powinna uwzględnić także wyłonienie grup wrażliwych. W pracy przedstawiono aktualny stan wiedzy dotyczący wpływu środowiskowych czynników chemicznych na rozwój raka pęcherza moczowego.

\section{The influence of environmental risk factors on the development of bladder cancer}

Every year the number of bladder cancer (UBC) cases is increasing. Global Analysis in 2009 registered 2.7 million diagnosed patients. Due to rising rates of morbidity and high costs of treatment, it is very important to identify risk factors for UBC and prevent at risk persons from further exposure. Environmental factors that have the proven strongest impact on the development of UBC include: smoking, aromatic amines, polycyclic aromatic hydrocarbons, nitrosamines, arsenic and cadmium. Experimental studies indicate carcinogenic effects of some urea-derived pesticides and organochloride pesticides on the uroepithelium. An important role is also played by inflammation, Schistosoma haematobium infections, exposure to ionizing radiation and immunosuppressive therapy. However, when exposure to second-hand smoking is considered, water disinfection byproducts, halogenated hydrocarbons, nitrites and nitrates, further studies are needed in order to clarify their role in the development of UBC. The relationship between environmental exposure and the morbidity rate is more pronounced in bladder cancer than in other cancers. Interaction between environmental factors and genetic susceptibility seems to be the most important risk factor. This was proven by studies of genotype of GST, NAT and other detoxifying enzymes genotypes. Genetic predisposition plays an important role and therefore prevention strategy should include determining such risk groups. This paper presents the current state of knowledge of the effects of environmental risk factors on the development of bladder cancer.

Słowa kluczowe: rak pęcherza moczowego, czynniki ryzyka, ksenobiotyki, palenie tytoniu

Key words: urinary bladder cancer, risk factor, xenobiotic, smoking

Wydział Farmaceutyczny z Oddziałem Analityki Medycznej

Katedra i Zakład Toksykologii

Uniwersytet Medyczny im. Piastów Śląskich we Wrocławiu

Pracę wykonano w ramach projektu MURO-Neo 


\section{Wstęp}

Rak pęcherza moczowego (UBC) jest czwartym nowotworem złośliwym i dziewiątą przyczyną zgonów u mężczyzn w USA. W roku 2011 zdiagnozowano tam 69250 nowych zachorowań i 14990 zgonów [1]. W roku 2008 odnotowano na świecie 386300 nowych przypadków i 150200 zgonów [2]. Analiza globalna z roku 2009 wskazuje na 2,7 mln przypadków UBC [3]. Nowotwór ten dotyka głównie ludzi starszych; 50\% przypadków to osoby powyżej 73 roku życia [4]. Rak ten jest piątym nowotworem w krajach zachodnich; średni wiek chorych to 69 lat u mężczyzn oraz 71 lat u kobiet. W ostatnich 20 latach liczba zachorowań rosła. Istotnym problemem są wysokie koszty leczenia. UBC uważany jest za najdroższy nowotwór, generujący najwyższe koszty od diagnozy do śmierci [5].

Chociaż etiologia raka pęcherza jest nieznana, zidentyfikowano wiele czynników, które mogą ten nowotwór powodować. Już w 1895 r. Ludwig Rehn, niemiecki lekarz, zaobserwował, że wśród pracowników zatrudnionych przy produkcji barwników anilinowych wzrosła zachorowalność na raka pęcherza. Przypuszczał, że powodem była ekspozycja na anilinę, czego nie potwierdziły późniejsze badania, jednak wykazały one rakotwórcze własności innych amin stosowanych w procesie produkcyjnym - benzydyny, 2-naftyloaminy czy 4-aminobifenylu [6].

Badania toksykologiczne na zwierzętach dostarczyły dowodów na właściwości rakotwórcze szeregu związków, ale dopiero dowody łączne z tych badań i z badań epidemiologicznych doprowadziły do ustalenia listy czynników chemicznych i innych zakwalifikowanych jako czynniki ryzyka rozwoju raka pęcherza. Należą do nich: palenie tytoniu, aminy aromatyczne, wielopierścieniowe węglowodory aromatyczne (WWA), nitrozoaminy, związki arsenu i kadmu oraz niektóre leki. Do nie do końca udowodnionych czynników środowiskowych należą: palenie bierne, chlorowanie wody, chlorowcowęglowodory, azotyny i azotany [6]. W pracy omówiono wyniki badań nad czynnikami chemicznymi wywołującymi raka pęcherza moczowego.

\section{Palenie tytoniu}

Spośród wymienionych czynników ryzyka UBC najwyraźniej udowodniony jest wpływ palenia papierosów. Najliczniejszą grupę chorych na raka pęcherza stanowią palacze papierosów, cygar oraz fajek. Wśród palaczy tytoniu notuje się nawet 4-krotnie częściej przypadki raka przejściowokomórkowego (TCC) niż u osób niepalących [5]. Natomiast po zaprzestaniu palenia odnotowuje się 30-procentowy spadek ryzyka rocznie przez kilka kolejnych lat. Jednakże osiągnięcie współczynnika bezpieczeństwa odpowiadającego osobom niepalącym może nie nastąpić nawet po 20 latach od zaprzestania palenia [7-9].

Ryzyko względne rozwojuTCC wśród osób palących tylko cygara lub fajki wynosi odpowiednio 1,8; 2,3 w porównaniu z osobami niepalącymi $[9,10]$. Również palacze bierni zali- czani są do grup ryzyka. Poddawani są oni ekspozycji na dym tytoniowy, który definiowany jest jako suma bocznego strumienia oraz dymu wydychanego przez palacza. Warty podkreślenia jest fakt, że stężenie niektórych związków w strumieniu dymu bocznego jest wielokrotnie większe niż w strumieniu głównym. Zależność ta dotyczy m.in. lotnych N-nitrozoamin, których zawartość może być nawet 6-100 razy większa [11].

Ponieważ dym tytoniowy zawiera ok. 60 karcynogenów, w tym 4-aminobifenyl, akrylonitryl, 2-naftyloaminy, toluidyny, N-nitrozodimetyloaminy, benzen, WWA, hydrazynę, arsen, kadm, polon 210, chlorek winylu, trudno określić jednoznaczną przyczynę rozwoju UBC. Najbardziej prawdopodobny jest łączny wpływ rakotwórczych czynników na mutacje genetyczne, jak również epigenetyczne oddziaływanie na procesy kancerogenezy. U palaczy tytoniu zidentyfikowano m.in. addukty DNA w moczu i stwierdzono uszkodzenia mechanizmów naprawczych DNA. Badania Freedmana wykazały, że 50-65\% chorych na raka pęcherza mężczyzn to palacze tytoniu [12]. Wśród kobiet ten wskaźnik jest niższy (20-30\%), lecz obecnie obserwuje się tendencję wzrostową. Wykazano, że palenie tytoniu jest przyczyną 50\% zachorowań na raka pęcherza. Naszym zdaniem istotnym wydaje się także mechanizm polegający na uwrażliwieniu palaczy na toksyny środowiskowe. Wynika to z upośledzenia procesów fagocytozy toksycznych pyłów środowiskowych z powodu uszkodzenia aparatu rzęskowego i słabej eliminacji toksyn. Ponadto składniki dymu tytoniowego wpływają znacząco na aktywność enzymów biorących udział w biotransformacji i w konsekwencji mogą nasilać procesy aktywacji toksyn środowiskowych (np. przemiany prokancerogenu — benzopirenu). Palenie tytoniu jest szczególnie szkodliwe dla osób z genetycznymi predyspozycjami wpływającymi na polimorfizm genów odpowiedzialnych za detoksykację (GST, NAT) czy procesy naprawcze DNA. Badania te potwierdzają tezę, że najistotniejszą przyczyną raka pęcherza może być narażenie środowiskowe w powiązaniu z wrażliwością osobniczą. Ustalanie zależności między paleniem tytoniu a rakiem pęcherza podjęto już w latach 50. XX wieku, jednak dopiero przeprowadzona na szeroką skalę metaanaliza dostarczyła wyraźnych dowodów [5].

Warte podkreślenia jest również podwójne znaczenie zaprzestania palenia: jako działanie prewencyjne w stosunku do raka pęcherza moczowego, jak również postępowanie zmniejszające częstość nawrotów oraz progresji u osób z już zdiagnozowaną chorobą. Ponieważ ocenia się, że ryzyko wystąpienia raka pęcherza u aktualnie palących jest 3,3-krotnie wyższe, a u tych, co palili w przeszłości, 2,1-krotnie wyższe, należy oszacować liczebność tej populacji i objąć ją programem prewencji [5].

\section{Aminy aromatyczne}

Aromatyczne aminy to związki, w których atom azotu jest związany z pojedynczym lub policyklicznym pierście- 
niem aromatycznym. Najprostszym związkiem jest anilina, szeroko stosowana w przemyśle i rolnictwie. Używana jest m.in. do produkcji barwników azowych, które w ludzkim organizmie są redukowane do aniliny. Anilina powstaje także podczas spalania przemysłowego WWA. Aminy aromatyczne są wykrywane w moczu palaczy. Związki z tej grupy dostają się do środowiska z zanieczyszczeniami przemysłowymi. Mogą być także wytwarzane przez mikroorganizmy obecne w ustroju człowieka z barwników azowych zawartych w wodzie czy żywności [13]. Źródłem amin aromatycznych mogą być również nitrozwiązki obecne w spalinach silnika Diesla, w potrawach grillowanych i in., które ulegają redukcji w przewodzie pokarmowym $[14,15]$. Dodatkowym zagrożeniem jest ekspozycja na dinitrotoluen.

Po raz pierwszy w 1895 r. Rehn zwrócił uwagę na związek między rakiem pęcherza a narażeniem na anilinę w przemyśle barwników. W roku 1954 Case wykazał 30-krotnie wyższą śmiertelność na raka pęcherza u pracowników produkujących barwniki, u których zidentyfikowano ekspozycję dermalną. Badania kohortowe potwierdziły zwiększone ryzyko zachorowań na UBC u osób eksponowanych na aminy aromatyczne, zatrudnionych w różnych gałęziach przemysłu (chemicznym, gumowym, tekstylnym oraz w rolnictwie) [16-18]. Także badania środowiskowe u ludzi żyjących w obszarze przemysłowym, z powietrzem zanieczyszczonym 2-naftyloaminą oraz benzydyną, wykazały dwukrotny wzrost zachorowań w latach 1950-1979. Po 60 latach badań wykazano, że długotrwała ekspozycja na 2-naftyloaminę, benzydynę i 4-aminobifenyl grozi rozwojem raka pęcherza, toteż w konsekwencji zakwalifikowano je jako związki o udowodnionym działaniu rakotwórczym dla ludzi (grupa 1 IARC). Ostatnio Międzynarodowa Agencja Badań nad Rakiem (IARC) zaliczyła do tej samej grupy orto-toluidynę i 4,4'-metylenobis(2-chloroanilinę) (MOCA) [19]. Działanie tych mutagenów opiera się na wytwarzaniu metabolitów, które atakują DNA. Za prawdopodobny kancerogen (grupa 2A IARC) uznaje się farby do włosów, szczególnie wśród kobiet z wolną acetylacją (fenotyp NAT2), zatrudnionych jako fryzjerki. Natomiast u kobiet farbujących włosy nie znaleziono wyraźnych dowodów na związek między UBC i stosowaniem farb, dlatego to ryzyko zaliczono do nieklasyfikowanej grupy 3 IARC [20]. W grupie prawdopodobnych kancerogenów znajdują się także 4-chloro-orto-toluidyna oraz auramina. Narażenie na aminy aromatyczne występuje w przemyśle farbiarskim, gumowym, skórzanym, tekstylnym, przy produkcji farb i lakierów, w drukarniach czy w zakładach fryzjerskich. Do grup zwiększonego ryzyka zalicza się także kierowców autobusów i mechaników samochodowych.

Mechanizm rakotwórczego działania amin aromatycznych jest znany i ściśle związany z zachodzącymi w organizmie procesami detoksykacji. Metabolizm aryloamin zapoczątkowują procesy hydroksylacji, które katalizowane są przez wątrobowy izoenzym CYP1A2 cytochromu p450 [7]. Zachodzi tu zarówno N-jak i C-hydroksylacja. Za toksyczne metabolity uważane są N-hydroksyloaminy, które mogą przechodzić w toksyczny kation arylonitreniowy. Kation ten ma zdolność tworzenia połączeń kowalencyjnych z makrocząsteczkami. Hydroksylowane aminy ulegają w organizmie reakcjom drugiej fazy detoksykacji m.in. reakcjom sprzęgania. Produkty sprzęgania wydalane są przez nerki najczęściej w postaci glukuronianów. Kwaśne środowisko panujące w pęcherzu moczowym oraz obecne $\operatorname{tam} \beta$-glukuronidazy aktywują częściową hydrolizę tych połączeń i powodują ponowne uwalnianie hydroksyloamin, które mogą tworzyć w pęcherzu toksyczne kationy. Uwolnione hydroksyloaminy mogą również ulegać acetylacji z udziałem NAT1, co prowadzi do syntezy silnie elektrofilowych acetoksyaryloamin, zdolnych do tworzenia toksycznych połączeń kowalencyjnych z urotelialnym DNA. Brak naprawy powstałego defektu DNA inicjuje mutacje w protoonkogenach oraz/lub nowotworowych genach supresorowych, co stanowi punkt krytyczny w nabywaniu przez normalne komórki uzłośliwionego fenotypu (transformacja nowotworowa). Natomiast NAT2 sprzyja detoksykacji polegającej na przekształcaniu amin w acetamidy, które zostają wydalone z organizmu [16]. W nabłonku pecherza moczowego zaobserwowano znaczną aktywność NAT1, kontrastującą z niską aktywnością NAT2. W procesie kancerogenezy znaczenie mają również szlaki wolnorodnikowe, tj. przemiany amin aromatycznych $z$ udziałem pęcherzowej syntazy prostaglandynowej (PHS) $[21,22]$.

\section{Wielopierścieniowe węglowodory aromatyczne}

Wielopierścieniowe węglowodory aromatyczne (WWA) to związki, które zawierają 2 lub więcej skondensowanych pierścieni benzenowych. Powstają zwykle podczas niepełnego spalania związków organicznych. Nie da się uniknąć narażenia na WWA, gdyż obecne są w spalinach samochodowych, w plastikowych i gumowych produktach oraz w gotowanym mięsie. W roku 1989 IARC zaliczyła narażenie zawodowe na spaliny silników benzynowych i Diesla jako rakotwórcze głównie z powodu zawartości WWA [23].

Udowodniony jest bezpośredni związek między narażeniem na WWA a rakiem płuc i skóry. Wpływ na raka pęcherza jest mniej oczywisty, chociaż osoby narażone (np. kierowcy ciężarówek) zapadają 1,2-2,3 razy częściej na nowotwory pęcherza niż generalna populacja. Zwiększone narażenie na WWA występuje u pracujących przy gazyfikacji węgla oraz w przemyśle metalowym. WWA (fenantren, antracen, benzopiren) uwalniają się także ze smoły węglowej, szczególnie podczas destylacji lub obróbki termicznej. Wykazano zwiększone ryzyko raka pęcherza u osób narażonych, zatrudnionych przy pracach asfaltowych, dachowych oraz produkcji aluminium [24, 25]. Także obecność WWA w powietrzu jest uważana za potencjalny czynnik ryzyka UBC [26]. 
W latach 80. zauważono, że kierowcy tirów, autobusów i taksówek częściej zapadają na raka pęcherza [27]. Szkodliwość narażenia na spaliny potwierdziły badania traktorzystów [28]. Jednak nie wszystkie prace dawały jednoznaczne wyniki. Badania belgijskie (200 przypadków z lat 1999-2004) nie wykazały zależności między ekspozycją na WWA a rakiem pęcherza [29], podobnie jak badania francuskie, holenderskie i inne [5, 30, 31]. Wydaje się, że skutki toksyczne spalin benzyny czy ropy zależą w dużym stopniu od warunków atmosferycznych (np. wilgotności powietrza i temperatury) i ogólnej jakości powietrza.

WWA, aminy aromatyczne i inne kancerogeny, m.in. akroleinę, formaldehyd, 2-amino-3,8-dimetyloimidazolochinoksalinę $\left(\mathrm{MeIQ}_{\mathrm{x}}\right.$ ) zidentyfikowano w oparach ze smażalni, a markery narażenia w moczu (8-hydroksypiren, 8-hydroksy-2'-deoksyguanidynę-8-OHdG) wykryto w moczu u pracowników chińskich restauracji [32]. Chociaż stwierdzona zależność między narażeniem na opary w smażalniach a zapadalnością na raka dotyczyła płuc, z uwagi na obecność 2-naftyloaminy i 4-aminobifenylu wydaje się, że także opary kuchenne można zaliczyć do czynników zwiększonego ryzyka raka pęcherza. Dodatkowo WWA, głównie benzopiren i benzofluoranten, wykryto w próbkach żywności (mięso, oleje roślinne, herbata) [33].

WWA dostają się do organizmu poprzez układ oddechowy, pokarmowy oraz przez skórę (kontakt bezpośredni podczas ekspozycji zawodowej). W organizmie człowieka ulegają biotransformacji przez mikrosomalny układ cytochromu p-450 (reakcje I fazy), w wyniku której dochodzi do przekształcenia nieaktywnych chemicznie węglowodorów w reaktywne związki epoksydowe. Hydrolaza epoksydowa oraz enzymy mikrosomalne katalizują przemianę epoksydów - poprzez pośrednie trans-dihydrodiole - do dioloepoksydów (ostateczne kancerogenne metabolity) [34]. Dioloepoksydy są silnym czynnikami alkilującymi, zdolnymi do tworzenia połączeń kowalencyjnych ze strukturami komórkowymi: RNA i DNA. Mechanizm ten jest odpowiedzialny za działanie kancerogenne i mutagenne tej grupy związków. Wybrane WWA ulegają także jednoelektronowej oksydacji katalizowanej przez cytochromy i peroksydazy, w wyniku której powstają reaktywne rodniki kationowe. Dodatkowo pośrednie trans-dihydrodiole mogą być poddane dalszemu utlenieniu przez izoformy aldo-keto reduktaz do reaktywnych ortochinonów [34]. Detoksykacja pochodnych epoksydowych i hydroksylowych polega na ich sprzęganiu, katalizowanym przez układy enzymatyczne, tj. GST, UGT, ST.

\section{Nitrozoaminy}

Nitrozoaminy zaliczane są do związków rakotwórczych, gdyż łatwo ulegają biotransformacji do kationu nitreniowego. Związki tej grupy mogą powstawać w żołądku przy podwyższonej wartości pH (3-5) z amin i aminokwasów wobec środków konserwujących, takich jak azotyny czy azo- tany. Niektóre nitrozoaminy, np. 4-hydroksybutylo(butylo) nitrozoamina (BBN), stosowane są do indukcji raka pęcherza w doświadczalnych modelach zwierzęcych [35].

\section{Związki arsenu i kadmu}

W latach 60. doszło w południowym Tajwanie do skażenia wody pitnej związkami arsenu, których stężenie osiągnęło wartości 0,7-0,9 mg/l. Po 20 latach stwierdzono 10-krotny wzrost zachorowań na raka pęcherza wśród populacji spożywającej zanieczyszczoną wodę (badania 1981-85) [5, 36]. Przyjęto, że stężenie arsenu w wodzie pitnej >0,2 mg/l jest czynnikiem ryzyka rozwoju UBC. Metaanaliza ekspozycji na niższe dawki arsenu nie wykazała zależności [37]. W badaniach Steinmausa i wsp. nie stwierdzono zależności przy dziennym pobraniu $80 \mu \mathrm{g}$ arsenu [38].

Badania populacji hiszpańskiej mieszkającej w pobliżu elektrowni i spalarni wykazały wśród tej ludności zwiększone ryzyko zachorowalności na raka pęcherza [39]. Autorzy wnioskują, że przyczyną może być emisja rakotwórczych metali. W roku 2001 uwolniono do powietrza w Hiszpanii 2 megatony (mt) arsenu, 1,8 mt kadmu, 66,4 mt niklu, $5,8 \mathrm{mt}$ chromu i innych kancerogenów, w tym WWA oraz aerozol stężonego kwasu siarkowego. Badacze hiszpańscy wykazali zwiększoną śmiertelność na raka pęcherza u mieszkańców z obszarów położonych poniżej 5 km od instalacji spalającej [39].

Belgia jest jednym z głównych producentów kadmu w świecie. Badania z 4 regionów w tym części prowincji Limburgii (dane z Limburg Cancer Registry) wykazały pozytywną korelację między stężeniem Cd we krwi a rakiem pęcherza. U chorych na raka średnia geometryczna zawartość kadmu we krwi była wyższa niż w grupie kontrolnej (odpowiednio 1,1 $\mu \mathrm{g} / \mathrm{l}$ i 0,7 $\mu \mathrm{g} / \mathrm{l}$ ). W badaniach 2327 osób z terenów zanieczyszczonych stwierdzono o 30\% wyższe wydalanie kadmu z moczem [40].

\section{Niektóre leki}

Chlornafazyna, pochodna 2-naftyloaminy, stosowana m.in. w chorobie Hodgkina, wywołuje raka pęcherza [41]. Lek ten został wycofany oraz umieszczony w grupie 1 IARC jako rakotwórczy dla ludzi. Wielu badaczy potwierdziło także związek między stosowaniem fenacetyny a zachorowalnością na raka pęcherza [42].

Metenamina (Cystex, Hiprex), szeroko stosowana w przeszłości w wielu krajach w infekcjach dróg moczowych, uwalnia formaldehyd i przy długotrwałym przyjmowaniu wywołuje raka pęcherza [43]. Także cyklofosfamid i izofosfamid stosowane w chemioterapii nowotworów uszkadzają śluzówkę pęcherza, prawdopodobnie z powodu uwalniania akroleiny w procesie biotransformacji [44]. Leki przeciwcukrzycowe z grupy pochodnych tiazolidynodionu: pioglitazon oraz rozyglitazon, stosowane dłużej niż 2 lata zwiększają znacząco ryzyko rozwoju raka pęcherza [45]. 
Także stosowana w chińskich pigułkach odchudzających roślina Aristolochia fangchi należy do roślin urotoksycznych. Stwierdzono związek przyczynowo-skutkowy u chorych na raka pęcherza, którzy przyjęli łączną dawkę $200 \mathrm{~g}$ A. fangchi. Toksyczne działanie spowodowane jest obecnością kwasów aristolochowych, pochodnych nitrofenantrenu (AAl; AAII) [46].

\section{Pestycydy}

Badania eksperymentalne przeprowadzone na szczurach wskazują na toksyczność niektórych pestycydów w stosunku do nabłonka dróg moczowych.

U szczurów karmionych diuronem (DCMU) [3-(3,4-dichlorofenylo)-1,1- dimetylomocznik], związkiem z grupy karbaminianów, zaobserwowano występowanie nekrozy komórek urotelialnych oraz obecność prostej hiperplazji w obrębie nabłonka pęcherza moczowego oraz miedniczek nerkowych. Uszkodzenia te widoczne były przy podawaniu Diuronu w dawce 500 ppm (part per milion, część na milion) w karmie [47]. W dalszych badaniach dowiedziono, że działanie kancerogenne tego herbicydu nie jest związane z działaniem genotoksycznym, lecz z ciągłą stymulacją proliferacji [48].

Analizowano także działanie urotoksyczne insektycydów z grupy polichlorowanych związków cyklicznych (pestycydy chloroorganiczne). Badanie przeprowadzone na grupie 50 pacjentów z rakiem pęcherza moczowego oraz na grupie osób zdrowych $(n=50)$ wykazały znaczący $(p<0,5)$ wzrost poziomu alfa $(\alpha)$, beta $(\beta)$, gamma $(\gamma)$, całkowitego haksachlorocykloheksanu oraz p,p-dichlorodifenylotrichloroetanu (p,p-DDT) we krwi osób chorych na raka pęcherza moczowego w odniesieniu do grupy kontrolnej oraz przewagę genotypu zerowego GSTM1 w grupie badanej. Wykryta zależność wskazuje na znaczenie interakcji gen - środowisko dla kancerogennych skutków pestycydów chloroorganicznych [49].

\section{Inne czynniki}

Wykazano zwiększoną zachorowalność na raka pęcherza u chorych z rakiem gruczołu krokowego poddanych radioterapii. Rak pęcherza może wystąpić jako skutek ekspozycji na promieniowanie jonizujące, zakażenie przywrą (schistosomatoza), chroniczne zapalenie oraz terapię immunosupresyjną. Ponad 55\% chorych na raka pęcherza w Egipcie było zainfekowanych pasożytem Schistosoma haematobium. Przetrwalniki przywry zanieczyszczają wody pitne, a dorosłe osobniki składają jaja, których obecność stwierdzono u chorych na raka pęcherza. Wywołany przez nie proces zapalny prowadzi do dysplazji komórek dróg moczowych [5]. Udowodniono wpływ procesu zapalnego na rozwój raka SCC (rak płaskonabłonkowy), natomiast mniej wyraźny jest związek z rozwojem UCC.
W obszernej metaanalizie obejmującej pacjentów po transplantacji nerek stwierdzono trzykrotnie zwiększone ryzyko rozwoju UBC [50]. Wydaje się, że przyczyną jest immunosupresja, gdyż podobną zależność zaobserwowano również u osób na długotrwałej doustnej terapii glikokortykosteroidowej [51].

Uważa się, że radioterapia przyczynia się do powstania wtórnych nowotworów nawet kilkadziesiąt lat po leczeniu guza pierwotnego. Po terapii radiacyjnej raka szyjki macicy, endometriozy czy raka gruczołu krokowego stwierdzono zwiększone ryzyko rozwoju raka pęcherza [5].

\section{Czynniki prawdopodobne}

Wiele doświadczeń na zwierzętach wskazuje na związek między ekspozycją na chlorowane węglowodory a rakiem pęcherza, szczególnie narażeniem na stosowany w pralniach chemicznych tetrachloroetylen (PER-tetrachloroetylen - gr. 2B IARC).

Stwierdzono także, że chlorowanie wody może powodować jej wzbogacenie w trichlorometan (THM) i kwasy chlorooctowe. Ostatnia metaanaliza wykazała związek między narażeniem na THM w stężeniu > $50 \mu \mathrm{g} / \mathrm{l}$ a zwiększonym ryzykiem raka pęcherza [52].

Do czynników ryzyka zalicza się także azotyny i azotany. Uważa się, że mogą one sprzyjać nitrozowaniu amin przez bakterie dróg moczowych [5].

Zagrożenie stwarza również wpływ sąsiedztwa instalacji spalających. Elektrownie wykorzystujące węgiel mogą zanieczyszczać środowisko w rakotwórcze metale $(\mathrm{Cr}, \mathrm{Ni}$, As, radionuklidy — radon, uran), WWA i inne. Badacze hiszpańscy wykazali zwiększoną śmiertelność na raka pęcherza w sąsiedztwie poniżej $5 \mathrm{~km}$ od instalacji spalającej [39]. Poza toksycznymi metalami i węglowodorami emitowane pyły zawierały duże ilości dwutlenku siarki. Wykazano rakotwórcze działanie $\mathrm{SO}_{2}$ dla zwierząt, a eksperci IARC (Inernational Agency for Research on Cancer) do czynników kancerogennych zaliczyli aerozol stężonego kwasu siarkowego.

\section{Czynniki genetyczne}

W przypadkach raka pęcherza moczowego związek między ekspozycją środowiskową a zapadalnością jest wyraźniejszy niż w innych nowotworach. Ponieważ $90 \%$ chorych to ludzie w wieku powyżej 55 lat, nie można lekceważyć wpływu długotrwałej ekspozycji środowiskowej. Prace nad wpływem czynników środowiskowych na rozwój UBC dawały często rozbieżne wyniki. Powodem wydaje się być zróżnicowana wrażliwość populacji ludzkiej (predyspozycje genetyczne), a także wieloskładnikowe narażenie, skutki odległe oraz znaczący wpływ stylu życia. Dla rozwoju raka pęcherza istotne są interakcje czynników środowiskowych z genetyczną wrażliwością. Strategia prewencji powinna więc uwzględniać wyłonienie grup wrażliwych. 
Zaobserwowano niejednoznaczny wpływ polimorfizmu genów transferazy glutationowej (GST), cytochromu P450, sulfotransferaz (ST) i N-acetylotransferaz (NAT), a także polimorfizmu systemów naprawczych DNA, np. glikozydazy oksyguaniny (OGG1). Stwierdzono zależność między genotypem NAT2, odpowiedzialnym za wolną acetylację, a zapadalnością na raka pęcherza [53]. Szczególnie wyższe ryzyko TCC stwierdzono u palaczy tytoniu z genotypem wolnej acetylacji NAT2, natomiast wpływ genów kodujących cytozolowy enzym detoksykacyjny GST na TCC wydaje się zróżnicowany. Badania palaczy tytoniu z zerowym wariantem GSTM1 wykazały 1,8 razy wyższe ryzyko rozwoju TCC niż u palaczy z przynajmniej jednym dzikim allelem [5]. Badania Yuan na grupie 731 chorych na raka pęcherza w porównaniu z grupą kontrolną (740) wykazały, że zerowy genotyp GSTM1, GSTT, oraz GSTP zwiększa zachorowalność o 19-48\% [54]. Jednak niektóre badania nie wykazują związku między rakiem pęcherza a zerowym genotypem GSTM1. Tak więc w tym obszarze konieczne są dalsze badania w celu weryfikacji wpływu polimorfizmów genów na zapadalność na UBC.

\section{Podsumowanie}

Przytoczone dane wskazują na niewątpliwy wpływ środowiska i stylu życia na nasze zdrowie, w tym na zapadalność na raka pęcherza. Wydaje się, że świadomość istniejących zagrożeń powinna skłaniać do unikania (redukcji) czynników ryzyka. Przedstawiony przegląd omawiający te czynniki umożliwi świadomą prewencję. Badania ilustrują, jak ważna jest dbałość o utrzymanie mechanizmów naprawczych i detoksykacyjnych w dobrej formie (styl życia). Należy także dążyć do wyłonienia i objęcia szczególnym nadzorem grup wrażliwych (predyspozycje genetyczne) oraz grup eksponowanych na czynniki ryzyka.

\section{Wykaz skrótów}

GST — transferaza glutationu

IARC — Międzynarodowa Agencja Badań nad Rakiem

NAT 1 - N-acetylotransferaza 1

NAT 2 - N-acetylotransferaza 2

ST — sulfotransferaza

TCC — rak przejściowokomórkowy pęcherza moczowego

UBC - urotelialny rak pęcherza moczowego

UGT-UDP — glukuronozylotransferaza

WWA — wielopierścieniowe węglowodory aromatyczne

\section{Konflikt interesów: nie zgłoszono}

\author{
Prof. dr hab. Anna Długosz \\ Katedra i Zakład Toksykologii \\ Uniwersytet Medyczny im. Piastów Śląskich \\ ul. Borowska 211, 50-556 Wrocław \\ e-mail:anna.dlugosz@umed.wroc.pl
}

Otrzymano: 3 lipca 2014 r.

Przyjęto do druku: 9 września 2014 r.

\section{Piśmiennictwo}

1. Jacobs BL, Montgomery JS, Zhang Y i wsp. Disparities in bladder cancer. Urol Oncol 2012; 30: 81-88.

2. Jemal A, Bray F, Center MM i wsp. Global cancer statistics. CA Cancer J Clin 2011; 61: 69-90.

3. Ploeg M, Aben KK, Kiemeney LA. The present and future burden of urinary bladder cancer in the world. World J Urol 2009; 27: 289-293.

4. Chung KT. The etiology of bladder cancer and its prevention. J Cancer Sci Ther 2013; 5: 346-361.

5. Kiriluk KJ, Prasad SM, Patel AR i wsp. Bladder cancer risk from occupational and environmental exposures. Urol Oncol 2012; 30: 199-211.

6. Lerner SP, Grossman HB, Messing EM i wsp. BCAN Think Tank session 3 : Prevention of bladder cancer. Urol Oncol 2010; 28: 338-342.

7. Brennan $\mathrm{P}$, Bogillot $\mathrm{O}$, Cordier $\mathrm{S}$ i wsp. Cigarette smoking and bladder cancer in men: A pooled analysis of 11 case-control studies. Int J Cancer 2000; 86: 289-294.

8. Strope SA, Montie JE. The causal role of cigarette smoking in bladder cancer initiation and progression, and the role of urologist in smoking cessation. J Urol 2008; 180: 31-37.

9. Wilhelm-Benartzi CS, Christensen BC, Koestler DC i wsp. Association of secondhand smoke exposures with DNA methylation in bladder carcinomas. Cancer Causes Control 2011; 22: 1205-1213.

10. McCormack VA, Agudo A, Dahm CC i wsp.: Cigar and pipe smoking and cancer risk in the European Prospective Invastigation into Cancer and Nutrition (EPIC). Int J Cancer 2010; 127: 2402-2411.

11. Pitard A, Brennan P, Clavel J i wsp. Cigar, pipe and cigarette smoking and bladder cancer risk in European men. Cancer Causes Control 2001; 12: 551-556.

12. Freedman ND, Silverman DT, Hollenbeck AR i wsp. Association between smoking and risk of bladder cancer among men and women. JAMA 2011; 306: 737-745.

13. Wang RF, Chen $\mathrm{H}$, Paine DD i wsp. Microarray method to monitor 40 intestinal bacterial species in the study of azo dye reduction. Biosens. Bioelectron 2004; 20: 699-705.

14. Singh R, Sram RJ, Binkova B i wsp. The relationship between biomarkers of oxidative DNA damage, polycyclic aromatic hydrocarbon DNA adducts, antioxidant status and genetic susceptibility following exposure to environmental air pollution in humans. Mutat Res 2007; 620: 83-92.

15. Szterk A. Chemical state of heterocyclic aromatic amines in grilled beef: evaluation by in vitro digestion model and comparison of alkaline hydrolysis and organic solvent for extraction. Food Chem Toxicol 2013; 62: 653-660.

16. Carreón T, Hein MJ, Viet SM i wsp. Increased bladder cancer risk among workers exposed to o-toluidine and aniline: A reanalysis. Occup Environ Med 2010; 67: 348-350.

17. Pira E, Piolatto G, Negri E i wsp. Bladder cancer morality of workers exposed to aromatic amines: A 58-years follow up. J Nat/ Cancer Inst 2010; 102: 1096-1099.

18. Volanis D, Kadiyska T, Galanis A i wsp. Environmental factors and genetic susceptibility promote urinary bladder cancer. Toxicol Lett 2010; 193: 131-137.

19. Baan R, Straif K, Grosse $Y$ i wsp. Carcinogenicity of some aromatic amines, organic dyes and related exposure. Lancet Oncol 2008; 9: 322-323.

20. Harling M, Schablon A, Schedlbauer G i wsp. Bladder cancer among hairdressers: A meta-analysis. Occup Environ Med 2010; 67: 351-358.

21. Murata M, Kawanishi S. Mechanisms of oxidative DNA damage induced by carcinogenic arylamines. Front Biosci (Landmark Ed) 2011; 16: $1132-1143$.

22. Neumann HG. Aromatic amines: mechanisms of carcinogenesis and implications for risk assessment. Front Biosci (Landmark Ed) 2010; 15: 1119-1130.

23. International Agency for Research on Cancer: IARC monographs on the evaluation of carcinogenic risks to humans. Diesel and gasoline engine exhausts and some nitroarenes. IARC Monogr Eval Carcinog Risks Hum 1989; 46: 1-458.

24. Ferrís J, Garcia J, Berbel O i wsp. Constitutional and occupational risk factors associated with bladder cancer. Actas Urol Esp 2013; 37: 513-522.

25. Stern FB, Ruder AM, Chen G. Proportionate mortality among unionized roofers and waterproofers. Am J Ind Med 2000; 37: 478-492.

26. Colli J, Lee BR, Thomas R. Population densities in relation to bladder cancer mortality rates in America from 1950 to 1994. Int Urol Nephrol 2012; 44: 443-449.

27. Silverman DT, Hoover RN, Mason TJ i wsp. Motor exhaust-related occupations and bladder cancer. Cancer Res 1986; 46: 2113-2116. 
28. Colt JS, Baris D, Stewart P i wsp. Occupation and bladder cancer risk in a population-based case-control study in New Hampshire. Cancer Causes Control 2004; 15: 759-769.

29. Kellen E, Zeegers MP, Paulussen A i wsp. Does occupational exposure to $\mathrm{PAHs}$, diesel and aromatic amines interact with smoking and metabolic genetic polymorphisms to increase the risk on bladder cancer? The Belgian case control study on bladder cancer risk. Cancer Lett 2007; 245: 51-60.

30. Clavel J, Mandereau L, Limasset JC i wsp. Occupational exposure to polycyclic aromatic hydrocarbons and the risk of bladder cancer: a French case-control study. Int J Epidemiol 1994; 23: 1145-1153.

31. Roelofzen JH, Aben KK, Van de Kerkhof PC i wsp. Dermatological exposure to coal tar and bladder cancer risk: A case-control study. Urol Oncol 2014 Mar 11. pii: S1078-1439(13)00508-5. doi: 10.1016/j. urolonc.2013.12.006.

32. Pan $\mathrm{CH}$, Chan CC, Wu KY. Effects on Chinese restaurant workers of exposure to cooking oil fumes: a cautionary note on urinary 8-hydroxy-2'-deoxyguanosine. Cancer Epidemiol Biomarkers Prev 2008; 17: 3351-3357.

33. Fontcuberta M, Arqués JF, Martínez M i wsp. Polycyclic aromatic hydrocarbons in food samples collected in Barcelona, Spain J Food Prot 2006; 69: 2024-2028.

34. Xue W, Warshawsky D. Metabolic activation of polycyclic and heterocyclic aromatic hydrocarbons and DNA damage: a review. Toxicol Appl Pharmacol 2005; 206: 73-93.

35. Lubet RA, Huebner K, Fong LY i wsp. 4-Hydroxybutyl(butyl)nitrosamine-induced urinary bladder cancers in mice: characterization of FHIT and survivin expression and chemopreventive effects of indomethacin. Carcinogenesis 2005; 26: 571-578.

36. Yu MC, Ross RK, Chan KKiwsp. GlutathioneS-transferase M1 genotypeaffects aminobiphenyl-hemoglobin adduct levels in white, black and Asian smokers and nonsmokers. Cancer Epidemiol Biomarkers Prev 1995; 4: 861-864.

37. Mink PJ, Alexander DD, Barraj LM i wsp. Low-level arsenic exposure in drinking water and bladder cancer: A review and meta-analysis. Regul Toxicol Pharmacol 2008; 52: 299-310.

38. Steinmaus $C$, Yuan $Y$, Bates MN i wsp. Case-control study of bladder cancer and drinking water arsenic in the western. United States. Am J Epidemiol 2003; 158: 1193-1201.

39. Garcia-Perez J, Pollan M, Boldo E i wsp. Mortality due to lung, laryngeal and bladder cancer in towns lying in the vicinity of combustion installations. Sci Total Environ 2009; 407: 2593-2602.

40. Kellen E, Zeegers MP, Den Hond ED i wsp. Blood cadmium may be associated with bladder carcinogenesis: The Belgian case-control study on bladder cancer. Cancer Detect Prev 2007; 31: 77-82.
41. Murta-Nascimento C, Schmitz-Dräger BJ, Zeegers MP i wsp. Epidemiology of urinary bladder cancer: from tumor development to patient's death. World J Urol 2007; 25: 285-295.

42. Nagata Y, Masuda A. Bladder tumor associated with phenacetin abuse: a case report and a review of the literature. Tokai J Exp Clin Med 2007; 32: 86-89.

43. Wang A, Robertson JL, Holladay SD i wsp. Measurement of DNA damage in rat urinary bladder transitional cells: improved selective harvest of transitional cells and detailed Comet assay protocols. Mutat Res 2007; 634: 51-59.

44. McCarroll N, Keshava N, Cimino M i wsp. An evaluation of the mode of action framework for mutagenic carcinogens case study: Cyclophosphamide. Environ Mol Mutagen 2008; 29: 117-131.

45. Lewis JD, Ferrara A, Peng T i wsp. Risk of bladder cancer among diabetic patients treated with pioglitazone: Interim report of a longitudinal cohort study. Diabetes Care 2011; 34: 916-922.

46. Lai MN, Wang SM, Chen PC i wsp. Population-based case-control study of Chinese herbal products containing aristolochic acid and urinary tract cancer risk. J Nat/ Cancer Inst 2010; 102: 179-186.

47. Nascimento MG, de Oliveira ML, Lima AS i wsp. Effect of Diuration [3-(3,4-dichlorophenyl)-1,1- dimethylurea] on the urinary bladder of male Wistar rats. Toxicology 2006; 224: 66-73.

48. Ihlaseh SM, Bailey KA, Hester SD i wsp. Transcriptional profile of diuron-induced toxicity on the urinary bladder of male Wistar rats to inform mode of action. Toxicol Sci 2011; 122: 330-338.

49. Sharma T, Jain S, Verma A i wsp. Gene environment interaction in urinary bladder cancer with special reference to organochlorine pesticide: a case control study. Cancer Biomark 2013; 13: 243-251.

50. Yan L, Chen P, Chen EZ i wsp. Risk of bladder cancer in renal transplant recipients: a meta-analysis. Br J Cancer 2014; 110: 1871$-1877$.

51. Dietrich K, Schned A, Fortuny J i wsp. Glucocorticoid therapy and risk of bladder cancer. Br J Cancer 2009; 101: 1316-1320.

52. Costet N, Villanueva CM, Jaakkola JJ i wsp. Water disinfection by-products and bladder cancer: Is there a European specificity? A pooled and meta-analysis of European case-control studies. Occup Environ Med 2011; 68: 379-385.

53. Zabost A, Zwolska Z, Augustynowicz-Kopeć E. Rola biologiczna prokariotycznych i eukariotycznych $\mathrm{N}$-acetylotransferaz. Pneumonol Alergol Pol 2013; 81: 137-144.

54. Yuan JM, Chan KK, Coetzee GA i wsp. Genetic determinations in the metaboslism of bladder carcinogens in relation to risk of bladder cancer. Carcinogenesis 2008; 29: 1386-1393. 